\title{
Solar-Assisted Electric Vehicle Charging Stations Interim Report
}

September 30, 2011

\author{
Oak Ridge National Laboratory \\ Tennessee Valley Authority \\ Electric Power Research Institute
}

Nissan, Inc. 


\title{
DOCUMENT AVAILABILITY
}

Reports produced after January 1, 1996, are generally available free via the U.S. Department of Energy (DOE) Information Bridge.

Web site http://www.osti.gov/bridge

Reports produced before January 1, 1996, may be purchased by members of the public from the following source.

\author{
National Technical Information Service \\ 5285 Port Royal Road \\ Springfield, VA 22161 \\ Telephone 703-605-6000 (1-800-553-6847) \\ TDD 703-487-4639 \\ Fax 703-605-6900 \\ E-mail info@ntis.gov \\ Web site http://www.ntis.gov/support/ordernowabout.htm
}

Reports are available to DOE employees, DOE contractors, Energy Technology Data Exchange (ETDE) representatives, and International Nuclear Information System (INIS) representatives from the following source.

Office of Scientific and Technical Information

P.O. Box 62

Oak Ridge, TN 37831

Telephone 865-576-8401

Fax 865-576-5728

E-mail reports@osti.gov

Web site http://www.osti.gov/contact.html

This report was prepared as an account of work sponsored by an agency of the United States Government. Neither the United States Government nor any agency thereof, nor any of their employees, makes any warranty, express or implied, or assumes any legal liability or responsibility for the accuracy, completeness, or usefulness of any information, apparatus, product, or process disclosed, or represents that its use would not infringe privately owned rights. Reference herein to any specific commercial product, process, or service by trade name, trademark, manufacturer, or otherwise, does not necessarily constitute or imply its endorsement, recommendation, or favoring by the United States Government or any agency thereof. The views and opinions of authors expressed herein do not necessarily state or reflect those of the United States Government or any agency thereof. 


\section{Table of Contents}

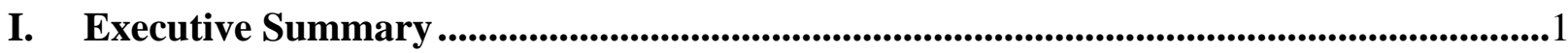

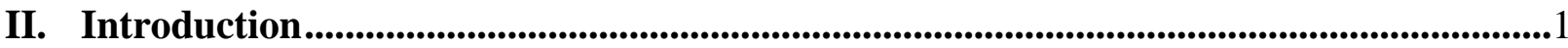

A. Overview of the Electric Vehicle Project ........................................................

B. ORNL Scope - The Solar-Assisted Electric Vehicle Charging Stations......................2

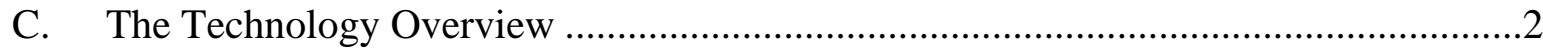

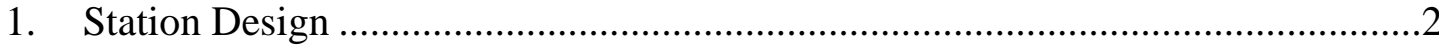

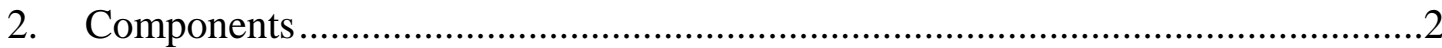

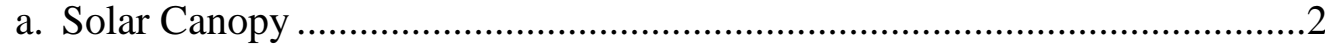

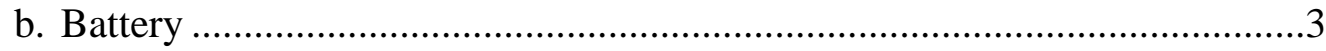

c. Electric Vehicle Supply Equipment .......................................................

d. Data and Communications ..........................................................................

III. The Sites

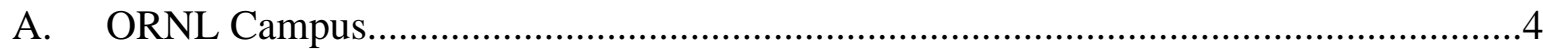

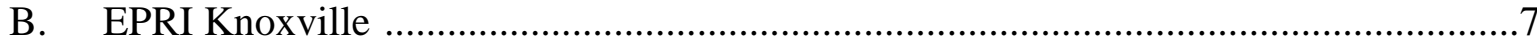

C. Smyrna, Nissan Administration Building ..............................................................10

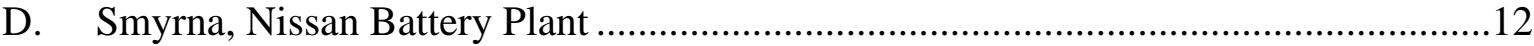

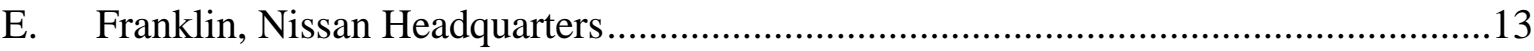

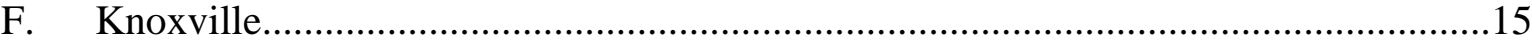

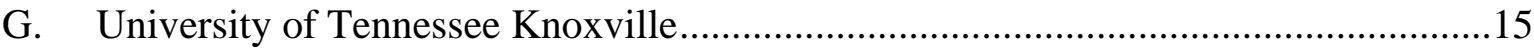

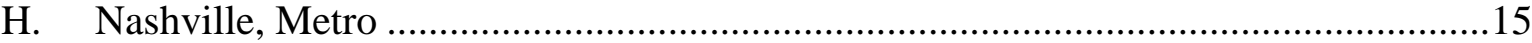

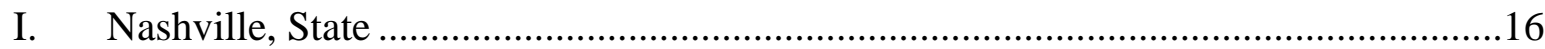

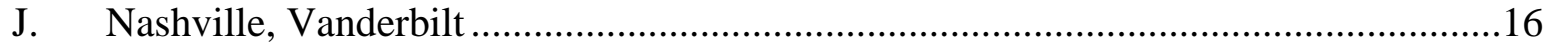

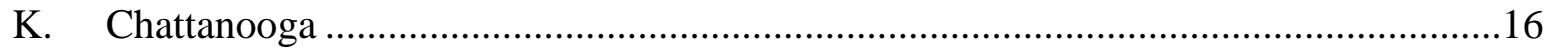

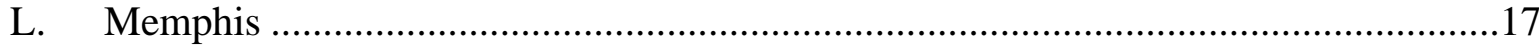

IV. Data Received from INL _.........................................................................................17

V. Lessons Learned - Technical Details ......................................................................18

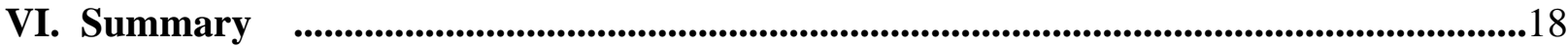

Appendix $A \quad$..............................................................................................................................19

Appendix B 



\title{
Solar-Assisted Electric Vehicle Charging Stations
}

\author{
Interim Report
}

\section{Executive Summary}

Oak Ridge National Laboratory (ORNL) has been awarded \$6.8 million in the Department of Energy (DOE) American Recovery and Reinvestment Act (ARRA) funds as part of an overall \$114.8 million ECOtality grant with matching funds from regional partners to install 125 solar-assisted Electric Vehicle (EV) charging stations across Knoxville, Nashville, Chattanooga, and Memphis. Significant progress has been made toward completing the scope with the installation of 25 solar-assisted charging stations at ORNL; six stations at Electric Power Research Institute (EPRI); and 27 stations at Nissan's Smyrna and Franklin sites, with three more stations under construction at Nissan's new lithium-ion battery plant. Additionally, the procurement process for contracting the installation of 34 stations at Knoxville, the University of Tennessee Knoxville (UTK), and Nashville sites is underway with completion of installation scheduled for early 2012.

Progress is also being made on finalizing sites and beginning installations of 30 stations in Nashville, Chattanooga, and Memphis by EPRI and Tennessee Valley Authority (TVA).

\section{Introduction}

\section{A. Overview of the EV Project}

On August 5, 2009, ECOtality North America was awarded a \$99.8 million ARRA grant from DOE to embark on the "EV Project," which was officially launched on October 1 , 2009, and will be completed on March 31, 2013. It was later announced that an additional \$15 million was granted allowing Fort Worth, Houston, and Washington, D.C. to be added, including making the Chevy Volt available in addition to the Nissan LEAF, as part of this project. The project is the largest deployment of electric vehicles and charging infrastructure in history. The EV Project will deploy up to 8,300 plug-in electric vehicles, 5,700 zero-emission Nissan LEAFs, 2,600 Chevy Volts, and more than 15,000 charging systems known as Electric Vehicle Supply Equipment (EVSE) to support them in strategic markets in six states (Arizona, California, Oregon, Tennessee, Texas, and Washington) and Washington, D.C. Nissan is making 1,000 LEAF EVs available for purchase in Tennessee, and ECOtality will install 2,410 non-solar charging stations in Tennessee.

The EV Project (http://theevproject.com) will collect and analyze data to characterize electric vehicle use in diverse topographic and climatic conditions, evaluate component reliability and the effectiveness of charge infrastructure, assess the impact of EVs on the electric grid, and conduct trials of various revenue systems for commercial and public charging infrastructure. The ultimate goal of the EV Project is to take the lessons learned from the deployment of these first EVs, and the charging infrastructure supporting them, to enable the streamlined deployment of the next five million EVs.

Charging infrastructure is being deployed in the following major population areas: Phoenix (AZ), Tucson (AZ), San Diego (CA), Portland (OR), Salem (OR), Eugene (OR), Corvallis (OR), Seattle (WA), Houston, (TX), Ft. Worth (TX), Nashville (TN), Knoxville (TN), Memphis (TN), Chattanooga (TN), and Washington, D.C. The Nissan LEAF 
became available in these areas in early 2011 to consumers and commercial fleets, and the Chevy Volt is being included in the project for Texas and Washington, D.C.

The EV Project will qualify 5,700 LEAF customers for participation based on driving characteristics and home electrical power capabilities. Because a significant percentage of vehicle charging will take place at EV drivers' residences, a portion of the EV Project funding supports home charging units installed by ECOtality. Participants will receive the home EVSE and installation at no cost in exchange for allowing the collection of vehicle and charge information from their homes and from publicly available EVSEs.

The EV Project also will install a significant number of publicly available EVSEs. ECOtality is working with local communities in planning the placement and deployment of these units. Both Level 2 and DC Fast Charging EVSEs will be provided.

\section{B. ORNL Scope - The Solar-Assisted EV Charging Stations}

In addition to the non-solar charging stations discussed above, the ORNL EV Project team (ORNL, TVA, EPRI, and Nissan) is installing 125 solar-assisted charging stations across Tennessee (Oak Ridge, Knoxville, Chattanooga, Nashville, Smyrna, Franklin, and Memphis). ORNL has been awarded \$6.8 million in ARRA funds (part of the original $\$ 99.8$ million), and regional partners are providing matching funds. As of this report date, 25 solar-assisted charging stations have been installed and are operating on the Oak Ridge National Laboratory campus, plus six at EPRI, and 27 at Nissan North America in Smyrna and Franklin, Tennessee.

\section{The Technology Overview}

1. Station Design - The primary component of a charging station, whether solar-assisted or not, is the EVSE. The solar-assisted charging stations use solar photovoltaic (PV) arrays to generate electricity to replenish the electricity used to charge the electric vehicles. The solar energy provided, per solar-assisted charging space throughout the year, is sufficient to offset the energy required to drive a vehicle like the Nissan LEAF almost 10,000 miles, thus reducing fossil fuel usage and greenhouse gas generation. Each charging station is also equipped with a battery bank. The purpose of the battery bank is to store electrical energy from the grid and discharge the stored energy during periods of peak charging demand, thus suppressing surge demand on the grid and mitigating the impact on local grid infrastructure, possibly avoiding the need to expand infrastructure to meet vehicle charging needs.

\section{Components}

a. Solar Canopy - Wherever practical, the PV solar array is mounted on a canopy above the solar-assisted EVSE parking spaces. In addition to providing a mounting structure for the solar PV array, the canopy provides shade and some protection from the elements, thereby keeping the vehicle battery cooler. The canopy solar PV modules are electrically connected in a parallel/series arrangement to supply the optimal direct current (DC) voltage to the inverter. The inverter converts direct current from the array to alternating current to feed to the power grid through a transformer. The canopy area over each space can support solar modules having a total capacity of about two kilowatts, which are expected to produce enough electricity in a year to offset an electric vehicle's typical annual electricity usage. 
b. Battery - Electrical utilities supplying power for the charging stations, whether solar-assisted or not, are concerned about surge loads on the grid from vehicle charging. The intent of the battery banks is to store energy on site, charging the batteries during periods of low charging demand, and discharging the batteries back into the electrical grid during high demand to minimize the surge load on the grid. The battery bank is equipped with an internet-connected charger/inverter unit. The charger/inverter can charge the batteries using power from the grid rectifying alternating current $(\mathrm{AC})$ to $\mathrm{DC}$, and it can reverse flow to feed power back into the grid by converting $48 \mathrm{~V}$ DC battery power to AC at the proper voltage. The charge/discharge cycles can be programmed to optimize performance in offsetting surge demand, and the charger/inverter can be controlled remotely via the internet.

c. Electric Vehicle Supply Equipment (EVSE) - The EVSEs used in this project are Level 2 chargers that output alternating current at 208 to $240 \mathrm{~V}$ AC at 30 amps. Rectification to DC is accomplished within the vehicle, via the on-board battery management system. Level 2 chargers can charge a fully depleted vehicle in approximately six to eight hours. The EVSEs are equipped with SAE J1772 connectors, the standard for Level 2 chargers. The EVSEs and J1772 connectors are compliant with the National Electric Code and have a number of important safety features:

- Interlocks with the EV drive system so the vehicle cannot be driven while connected to the charger.

- De-energizes if the cable or connector is subjected to strain.

- Provides charge current interrupting device with automatic test for personal protection.

- De-energizes connector parts until the connector is properly latched into the vehicle socket. The connector is automatically de-energized before being unplugged from the vehicle.

Some of the EVSEs are activated by a radio frequency identification card (RFID), similar to a credit card, which is assigned to each user. This will provide a means of billing customers when the charging stations become commercial.

d. Data Collection and Communications - The EVSEs, solar PV inverters, and the battery charger/inverter units are all internet-connected. During the research portion of the project, EVSE usage data for each charging event is being collected and sent to Idaho National Laboratory (INL) for analysis and interpretation with regard to vehicle performance, maintenance, and operational issues. 


\section{The Sites}

\section{A. ORNL Campus (25 Stations)}

A 25-space solar-assisted charging station was opened on the North Parking Lot of ORNL's main campus in March 2011. A formal dedication and ribbon cutting was held on May 25, 2011, and was attended by the DOE sponsor and numerous regional partners including: TVA, Nissan, EPRI, ECOtality, the State of Tennessee, and the news media. As of this writing, there are 15 Nissan LEAF owners at ORNL using the charging station.

A $47 \mathrm{~kW}$ solar PV array on the canopy currently supplies more

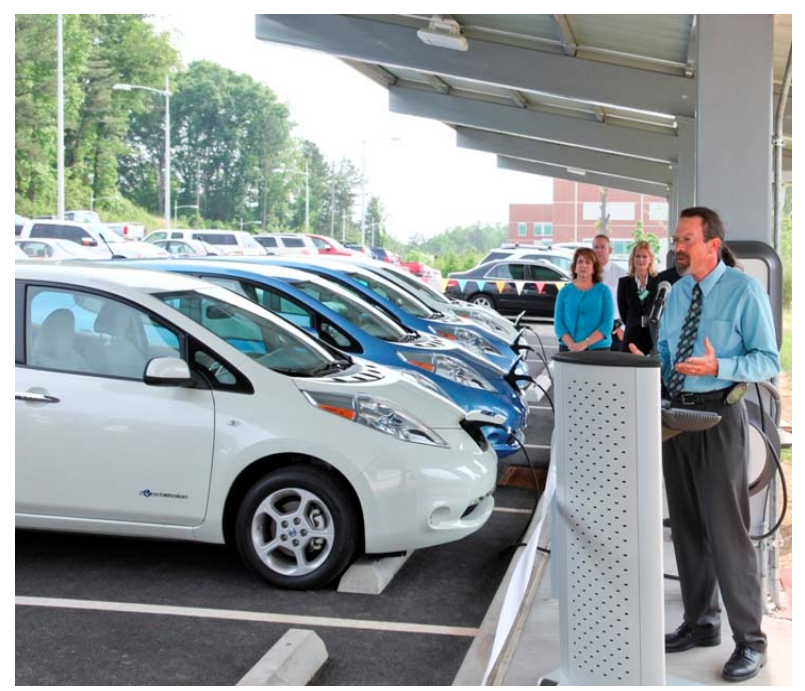

DOE Vehicle Systems Program Manager, Lee Slezak, speaking at the event.

energy than the existing number of LEAFs consume. The charging station is equipped with a $\sim 84 \mathrm{kWh}$ battery bank. Optimization studies are planned to determine the most effective charge/discharge protocol to minimize surge loads on the grid and maximize battery life. Charging data from the station is transmitted to ECOtality, then collected and analyzed by INL. No personal information is used. The reduced data collected to date is presented in this report. The following is a diagram of the ORNL system.

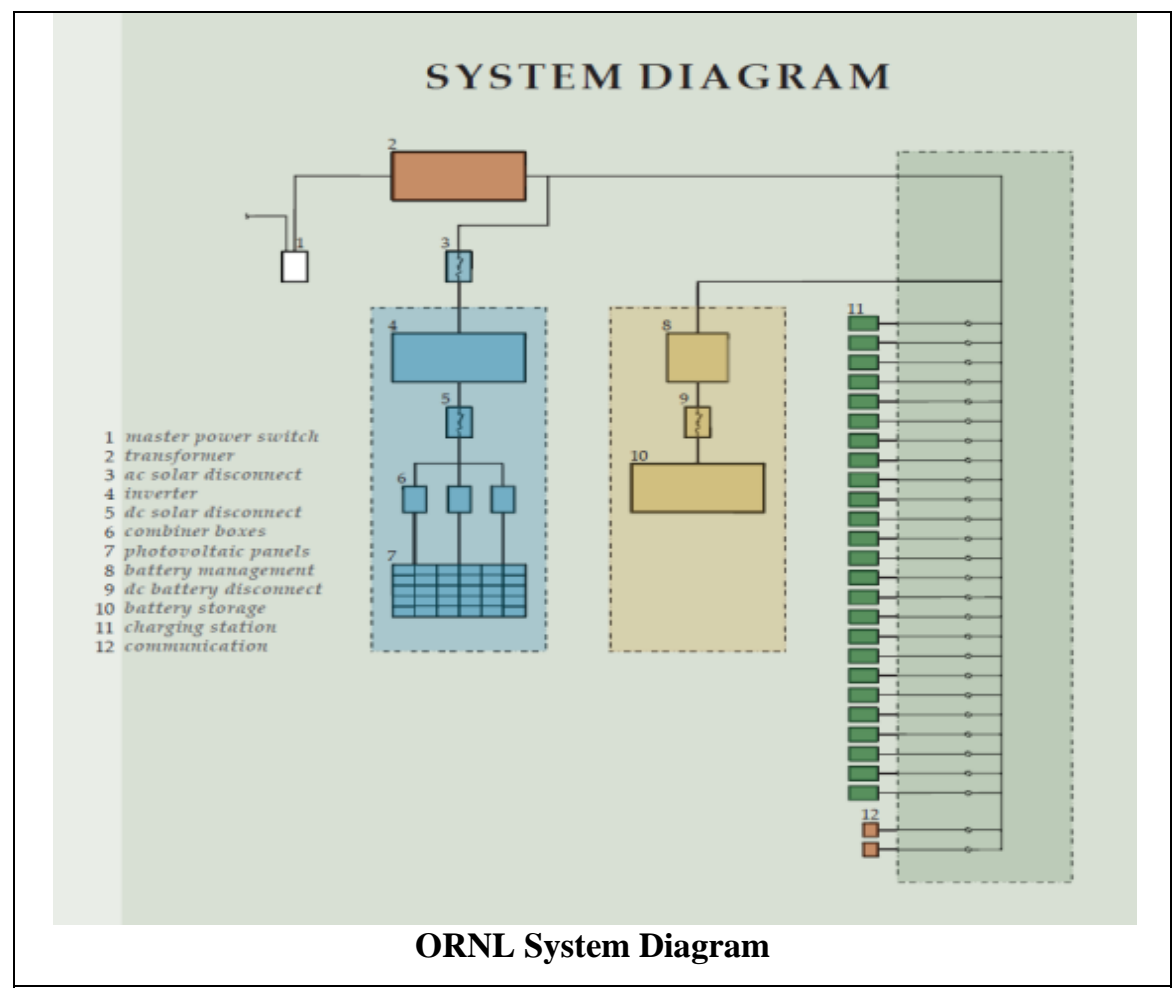


Solar: The 47kW ORNL solar canopy is outfitted with 210 Sharp ND-224UC1 modules rated at $224 \mathrm{~W}$ each. The modules are composed of multi-crystalline silicon solar cells, with a module efficiency of $13.74 \%$. The solar canopy measures approximately 235 by 20 feet in plan and is tilted 10 degrees toward the south. The structure is a moment-resisting frame constructed of rectangular hollow structural sections.

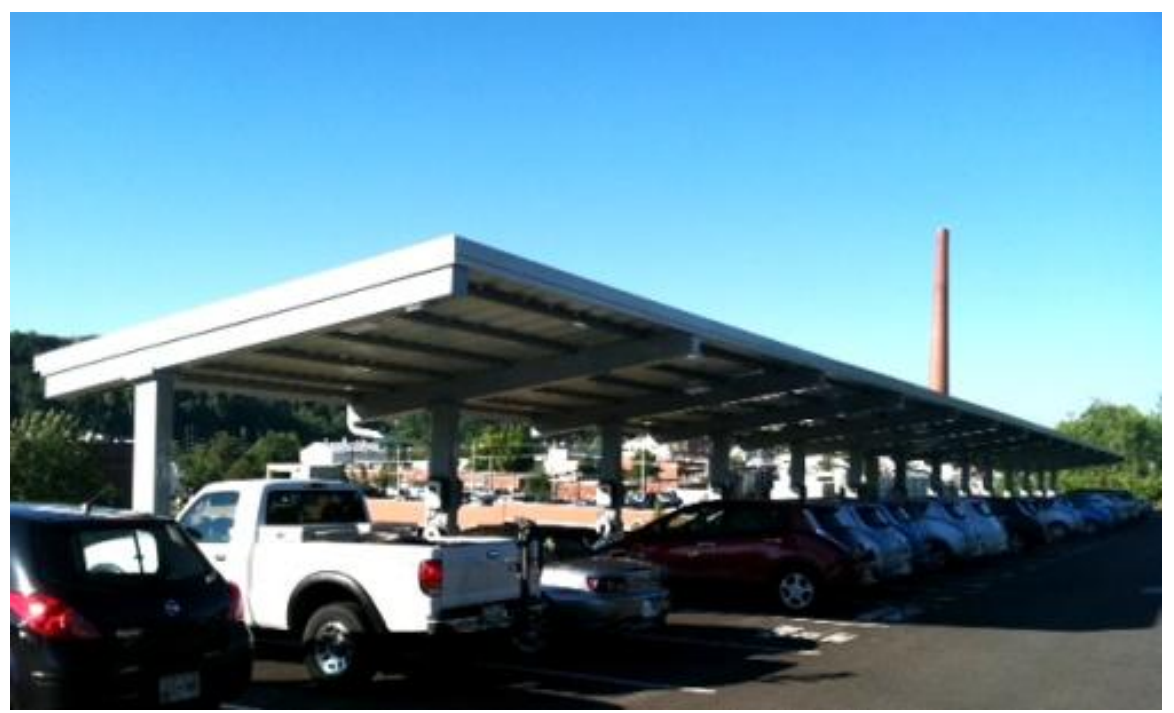

ORNL Solar-Assisted EV Charging Station

Fourteen single column frames spaced at 18 feet support tubular steel purlins and the standing seam metal roof to which the solar photovoltaic (PV) modules are attached. The solar PV modules are electrically connected in series strings of 14 modules each to produce $600 \mathrm{~V} \mathrm{DC}$, for optimum performance with the DC to AC inverter. Fifteen such series strings are connected in parallel at three Solar BOS circuit combiners to produce 75 amps at full

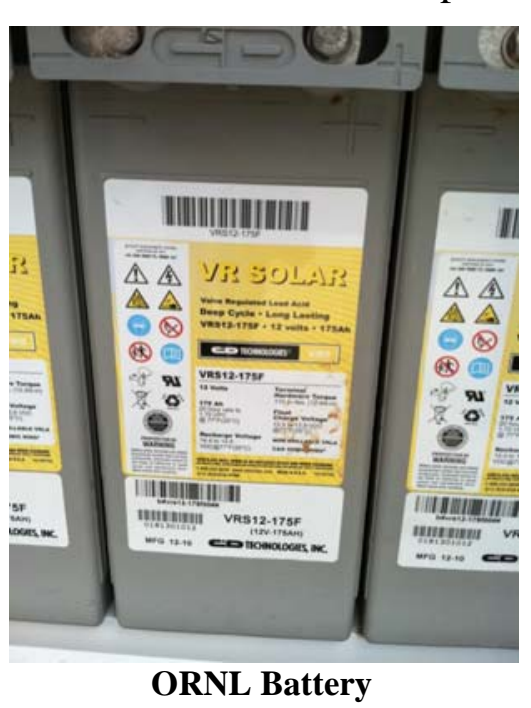
nameplate rating.

The three combiners feed a PV Powered 50 $\mathrm{kW}$ inverter. The inverter converts the 600 VDC to 208 VAC 3phase at $\sim 96 \%$ efficiency. The AC voltage is increased by a transformer and feed onto the ORNL power grid.

Battery: The ORNL solar-assisted EV charging station is equipped with a 40-battery bank. The batteries are model VRS12-175F as manufactured by C\&D Technologies, Inc. Each valve-regulated lead acid deep cycle battery consists of six cells and is rated at 175 amp-hours (20-hour rate to $1.75 \mathrm{~V}$ per 
cell) for a total of 7,000 amp-hours, or nominally $84 \mathrm{kWh}$. The battery bank is enclosed in an air-conditioned steel cabinet.

The battery bank is charged and can be discharged by an SMA Technologies AG Sunny Island 5048 inverter/charger. The Sunny Island is a bi-directional inverter, meaning that it is an inverter and a battery charger, and is tied to the grid. The Sunny Island converts AC line voltage to DC for battery charging. The charge profile can be customized to match the specific batteries to maximize battery life. It is also capable of performing equalization charge to balance the individual cells. The Sunny Island is also an inverter capable of discharging

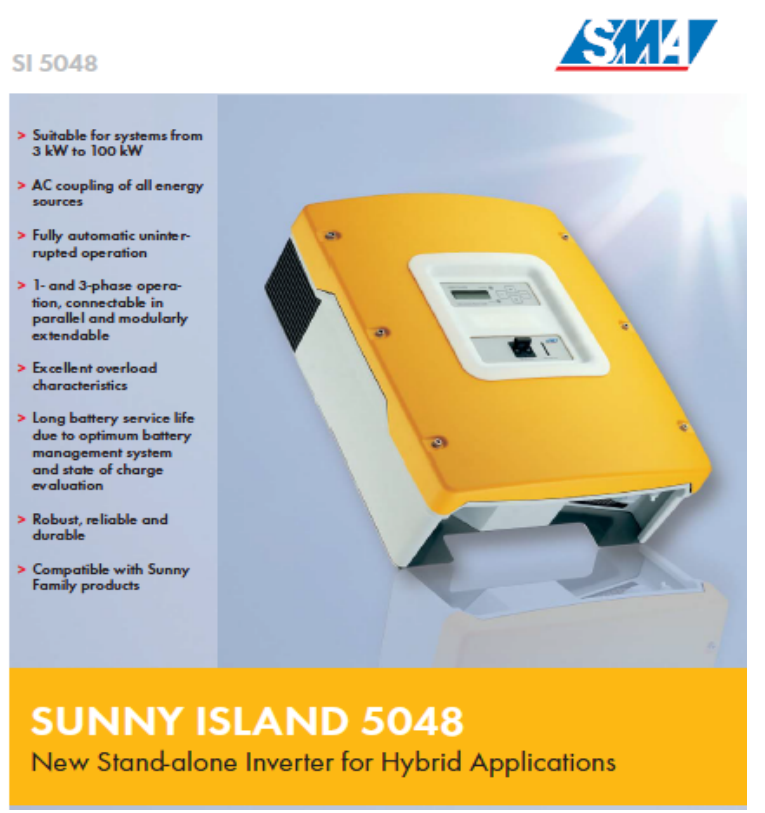

ORNL Battery Charger/Inverter energy stored in the battery bank to the power grid to help offset load surges from EV charging. The Sunny Island's rated continuous AC output is $5 \mathrm{~kW}$ at $25^{\circ} \mathrm{C}$. The discharge profile can be customized to maximize battery life, to maximize energy to the grid, or to compromise between the two objectives. In inverter mode, the Sunny Island is essentially a smaller version of the solar PV inverter.

EVSEs: ORNL has 25 Blink EVSEs that are manufactured by ECOtality. The Blink EVSEs include all of the features mentioned above, plus they have internet connectivity. They can be configured to use Wi-Fi, hardwire Ethernet, or CDMA (a cell phone protocol).

Data and Communication: The EVSEs, solar PV inverters, and the battery

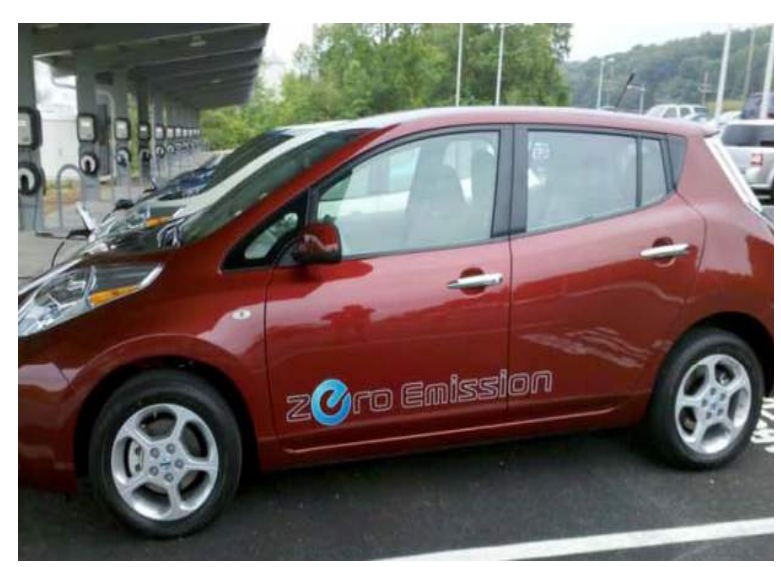
charger/inverter units are all internetconnected. During the research portion of the project, EVSE usage data is being collected and analyzed by INL. The data available for the ORNL units is included in this report. Data from the solar inverters and battery charger/inverter units will be collected and analyzed by ORNL through the vendor servers. Communications with the devices is twoway so that control commands can be sent to them. 


\section{B. EPRI Knoxville (Six Stations)}

TVA and EPRI held a ribbon cutting on January 25, 2011, for EPRI's six solar-assisted charging stations installed at EPRI's West Knoxville laboratory. The event was well attended and received considerable press coverage, including from the New York Times. TVA arranged to have a Nissan LEAF, a Chevy Volt, and two Mitsubishi iMiEVs on site, and test drives were made available.

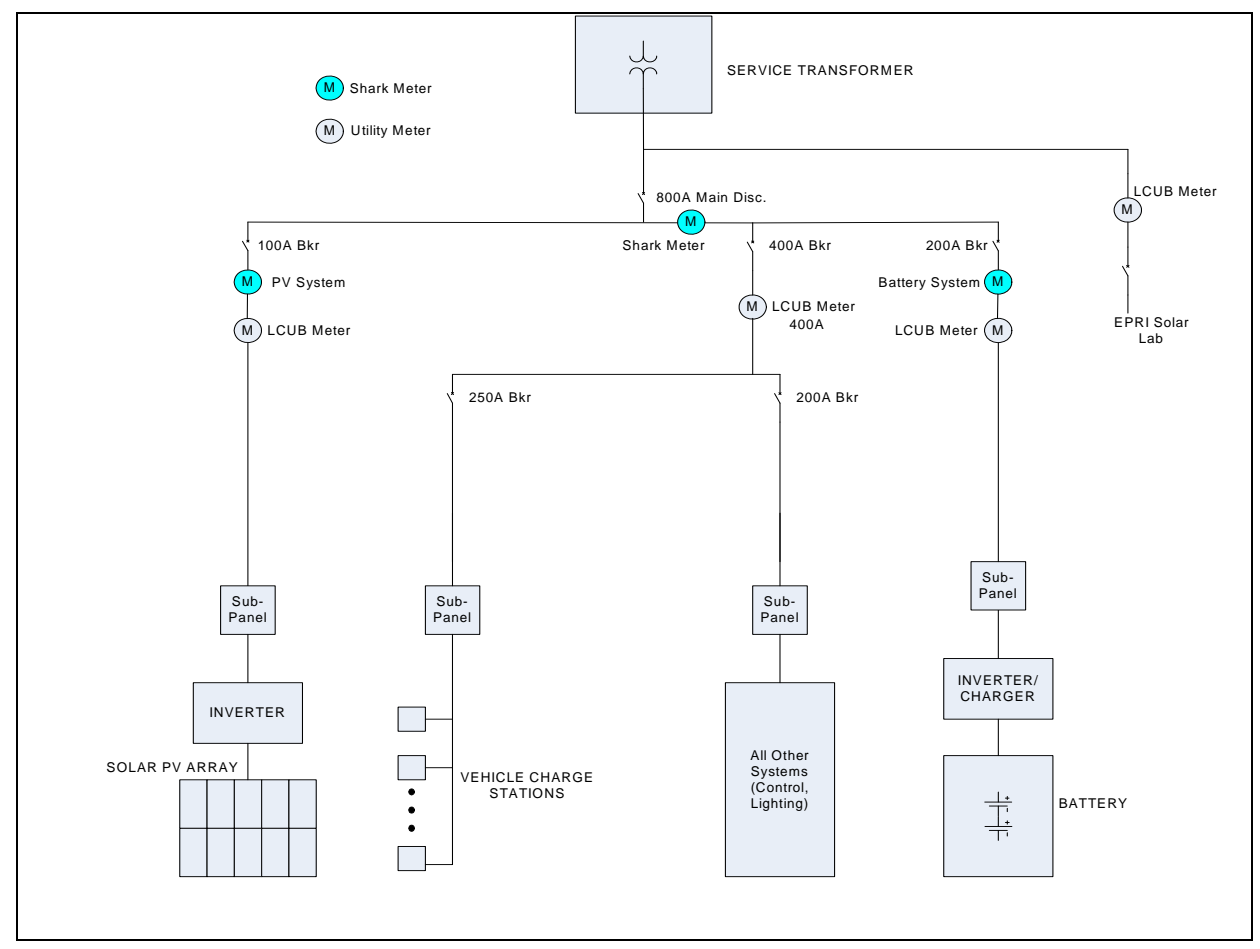

EPRI System Diagram

Solar: The $12 \mathrm{~kW}$ system at the EPRI Knoxville facility is outfitted with 60 REC Solar AE210-USA modules rated at 210 $\mathrm{W}$ each. The modules are composed of multi-crystalline silicon solar cells, with a module efficiency of $12.7 \%$. Each solar module is connected to an Enphase M19072-240-S12 micro-inverter. The solar canopy measures approximately 63 by 20 feet in plan and is tilted three degrees toward the south. The structure is a moment-resisting frame constructed of rectangular hollow structural sections.

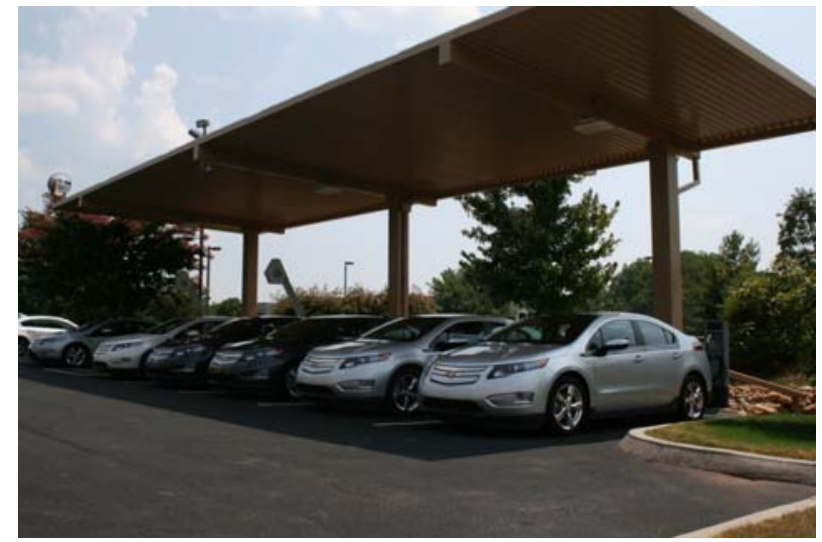

EPRI Solar Canopy

Three single column frames spaced at 23 feet support tubular steel purlins to which the solar PV modules are attached. A standing seam metal roof is attached to the underside of the purlins to ensure that the canopy is drip-tight. The outputs of the micro-inverters are electrically connected in parallel strings of 15 modules each to produce 240 AC. 
Four such parallel strings are connected, each via an AC disconnect, in parallel to provide the full system capacity.

\section{EPRI Solar Canopies}
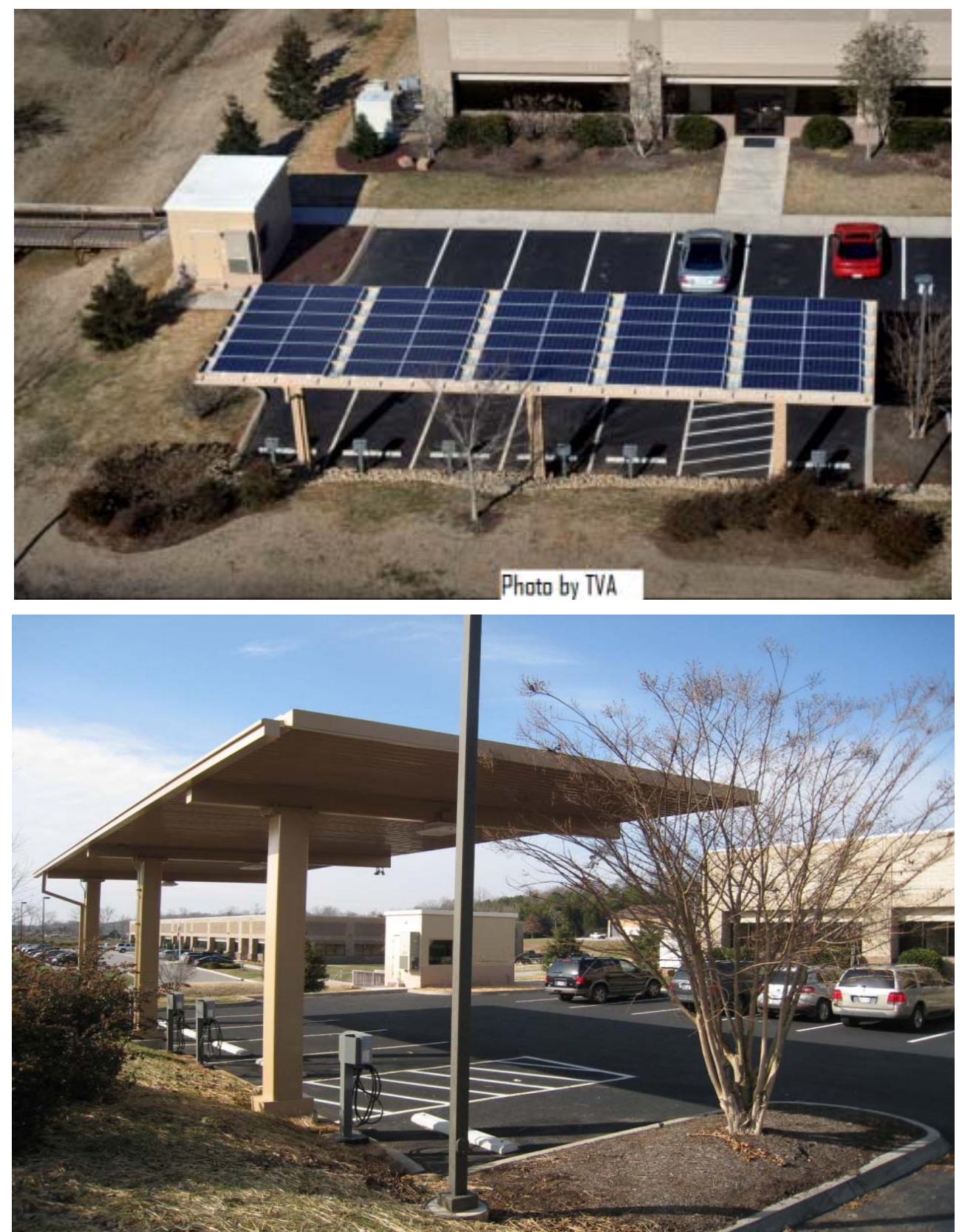

Battery: The EPRI TVA SMART TM Station battery storage system consists of three, Silent Power Model 10000 battery cabinets. Each cabinet provides up to $9.2 \mathrm{~kW}$ of peak output power with a usable storage capacity of $10 \mathrm{kWh}$ (actual battery capacity is roughly $15 \mathrm{kWh}$ ) for a total of $27.6 \mathrm{~kW}$ of peak capacity with a $30 \mathrm{kWh}$ usable capacity for all three systems. The battery system in each cabinet consists of $48 \mathrm{GS}$ Yuasa SLC70-4 advanced lead acid batteries wired in series/parallel strings to form a nominal 48 V DC bus. The Silent Power units have a built in battery charging system with a $3 \mathrm{~kW}$ rating per cabinet. 


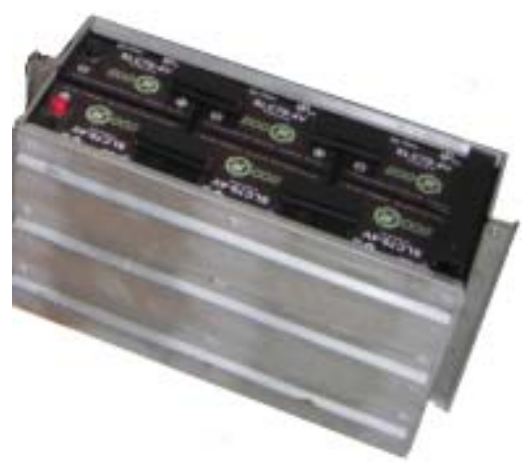

EPRI Battery Drawer

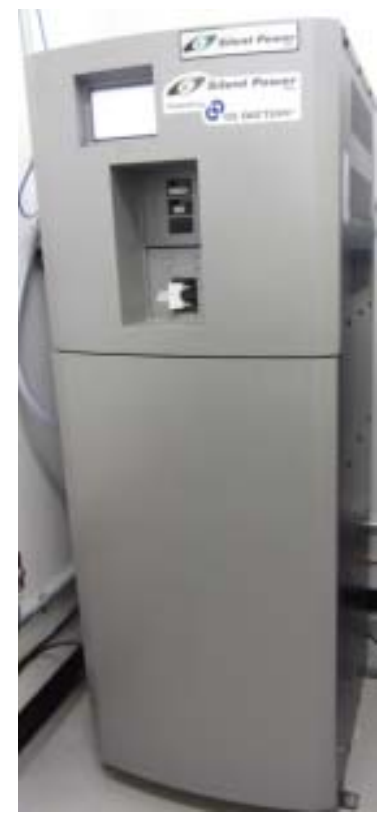

EPRI Silent Power Battery System

EVSEs: EPRI completed their initial Knoxville installation with Clipper Creek DS-100 EVSEs. During 2011, four of the original EVSEs were replaced with two EVSE LLC Model 3722 overhead cable units and two Eaton SBR3BX00000 pedestal EVSEs. EPRI plans to evaluate other EVSEs over the duration of the project. The two remaining Clipper Creek units were retrofitted with Liberty Plug-Ins access control keypads during 2011. EPRI intends to deploy a variety of EVSE types and brands at future sites.

Data and Communications: All data being logged at EPRI site is moved via cellular modem or internet connection to a data base system located in Knoxville, Tennessee. Data can be extracted from this database for external reporting. EPRI is working

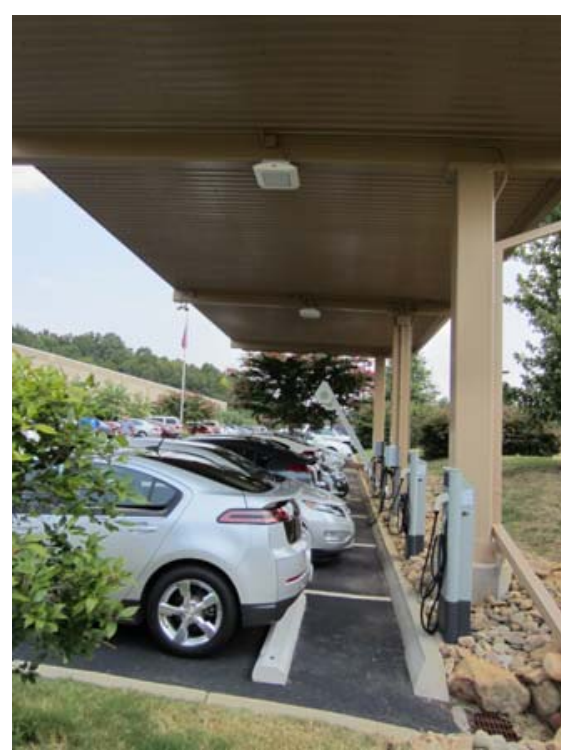

EPRI EVSEs to develop a data extractor program for providing project data to INL. Other data uses include local data display as shown below. Data collected at the EPRI site are shown below. Details of the EPRI data are listed in Appendix B. 


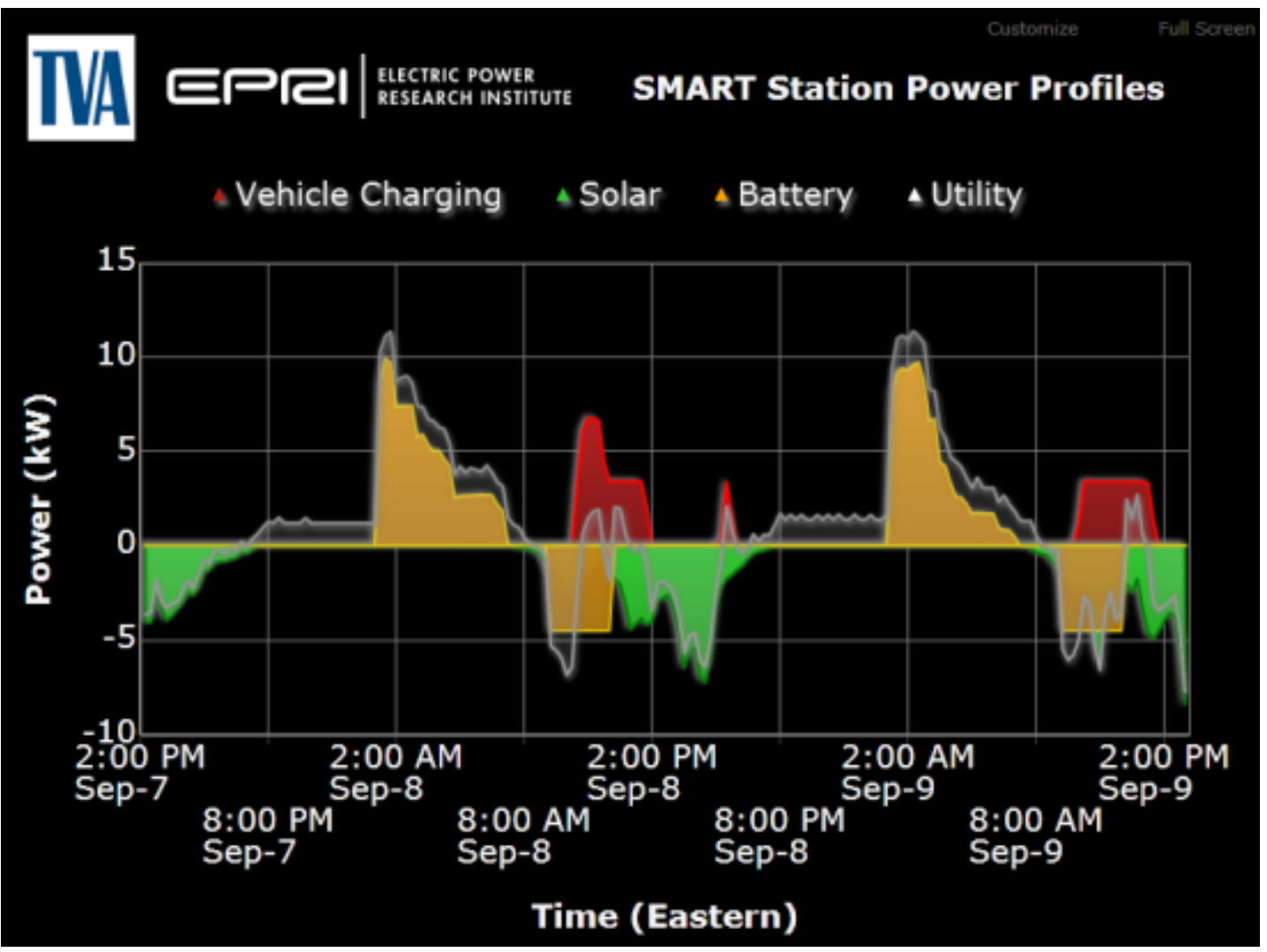

Data Collected at the EPRI Site

\section{Smyrna, Nissan Administration Building (Nine Stations)}

Nissan has completed nine solar-assisted charging stations at its Smyrna plant.

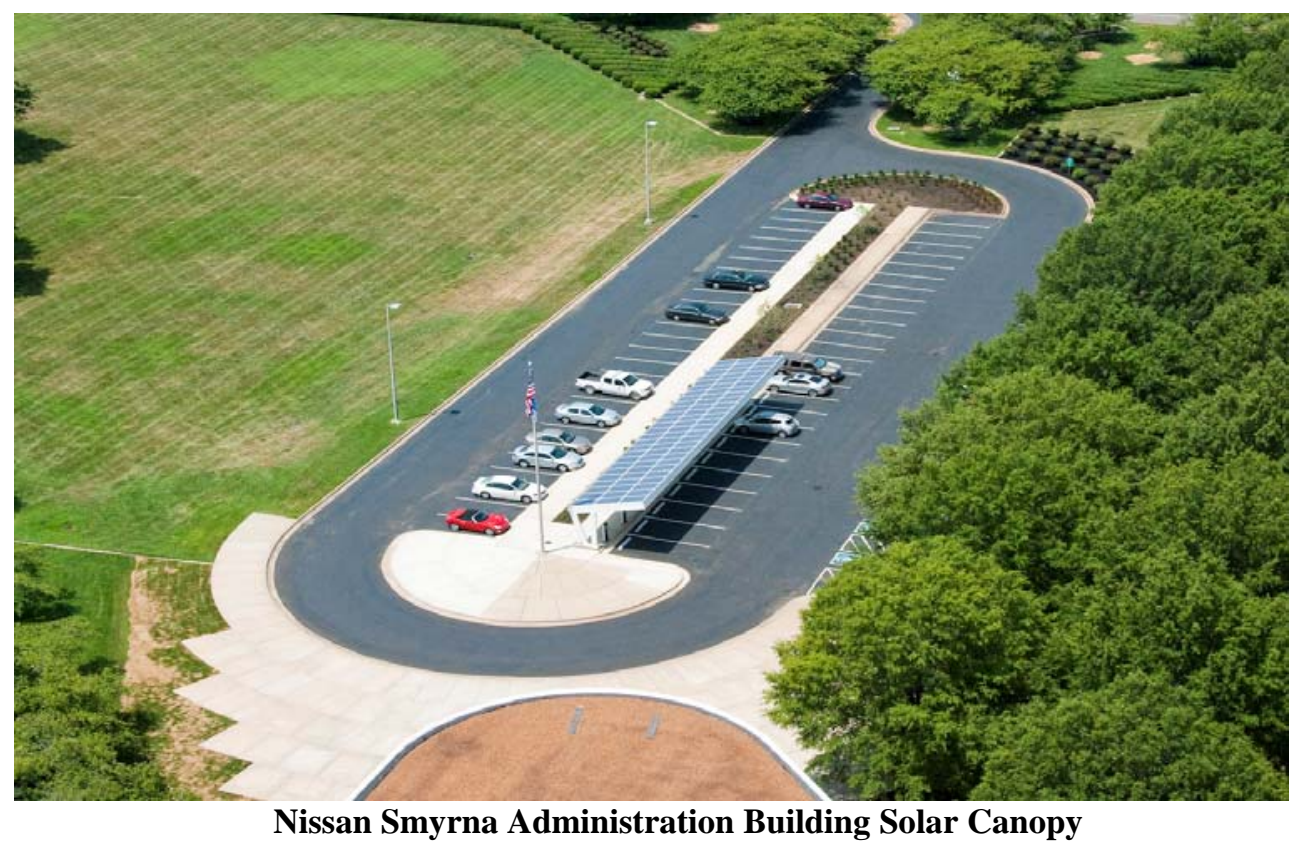


Solar: The $19 \mathrm{~kW}$ Nissan solar canopy covering nine EV charging spaces is designed with Sharp NU-U235F1 modules rated at $235 \mathrm{~W}$ each. The modules are composed of mono-crystalline silicon solar cells, with a module efficiency of $14.4 \%$. The solar canopy measures approximately 87 by 17 feet in plan and is tilted 10 degrees toward the south. The structure is a moment-resisting frame constructed of rectangular hollow structural sections with four single main columns. The PV array is mounted on top of the steel with a Florian PV racking system that provides a weather-tight roof structure. The solar PV modules are electrically connected in series strings of nine modules each to provide DC voltage to a Xantrex GT30 DC to AC inverter. Eight such series strings are connected in parallel at two Solar BOS circuit combiners to form a bi-polar system, one negative combiner and one positive combiner.

Battery: The Nissan solar-assisted EV charging station is equipped with a single lithium ion battery out of a LEAF automobile. The battery storage component is a 90 kW lithium ion battery designed with a control system to shave electrical demand during peak charging periods. The use of LEAF lithium batteries for energy storage will provide a second-life use for the electric vehicle batteries. Most used batteries will have a $60-70 \%$ life remaining. The battery is rated at $24 \mathrm{kWh}$ and is stored in a conditioned electrical equipment room. The battery is charged by a special battery charger design by Nissan, Schneider Electric, and Bomitron.

The battery is discharged to the utility grid utilizing a Xantrex GT 100 DC to DC to AC inverter. This inverter is capable of discharging energy stored in the battery bank to the power grid to help offset load surges from EV charging. The discharge profile can be customized to maximize battery life, shave peak demands, and discharge at predefined outputs and to maximize energy to the grid.

EVSEs: Nissan has nine Blink EVSEs that are manufactured by ECOtality at their administration building. The Blink EVSEs include internet connectivity. They can be configured to use Wi-Fi, hardwire Ethernet, or CDMA (a cell phone protocol).

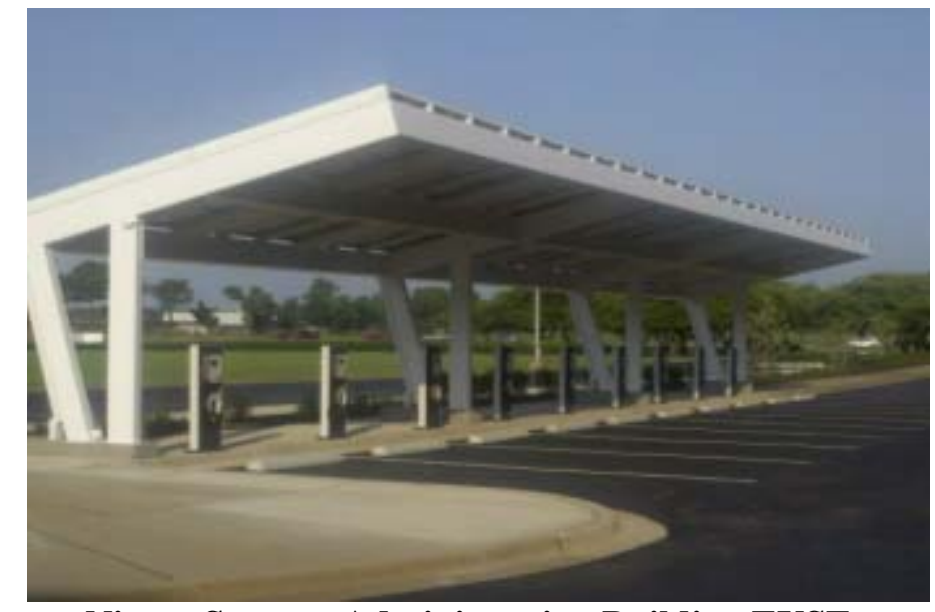

Nissan Smyrna Administration Building EVSEs

Data and Communications: TBD 


\section{Smyrna, Nissan Battery Plant (Three Stations)}

Nissan is currently installing three solar-assisted charging stations at its New Lithium Ion Battery plant in Smyrna, Tennessee. Completion timing is scheduled for December $1,2011$.

Solar: The $6.5 \mathrm{~kW}$ Nissan solar canopy to cover three EV charging spaces (currently under construction) is designed with Sharp NU-U235F1 modules rated at $235 \mathrm{~W}$ each. The modules are composed of mono-crystalline silicon solar cells, with a module efficiency of $14.4 \%$. The solar canopy measures approximately 30 by 17 feet in plan and is tilted 10 degrees toward the south. The structure is a moment-resisting frame constructed of rectangular hollow structural sections with four single main columns. The PV array is mounted on top of the steel with a Florian PV racking system that provides a weather-tight roof structure. The solar PV modules are electrically connected in series strings of nine modules each to provide DC voltage to a Xantrex GT30 DC to AC inverter. Four such series strings are connected in parallel at two Solar BOS circuit combiners to form a bi-polar system, one negative combiner and one positive combiner.

Battery: The Nissan solar-assisted EV charging station is equipped with a single lithium ion battery out of a LEAF automobile. The battery storage component is a 90 $\mathrm{kW}$ lithium ion battery designed with a control system to shave electrical demand during peak charging periods. The use of LEAF lithium batteries for energy storage will provide a second-life use for the electric vehicle batteries. Most used batteries will have a $60-70 \%$ life remaining. The battery is rated at $24 \mathrm{kWh}$ and is stored in a conditioned electrical sub-room. The battery is charged by a special battery charger design by Nissan, Schneider Electric, and Bomitron.

The battery is discharged to the utility grid utilizing a Xantrex GT 100 DC to AC inverter. This inverter is capable of discharging energy stored in the battery bank to the power grid to help offset load surges from EV charging. The discharge profile can be customized to maximize battery life, shave peak demands, and discharge at predefined outputs and to maximize energy to the grid.

EVSEs: Nissan will have three Blink EVSEs that are manufactured by ECOtality at their battery plant. The Blink EVSEs include internet connectivity and can be configured to use Wi-Fi, hardwire Ethernet, or CDMA (a cell phone protocol).

Data and Communications: TBD 


\section{E. Franklin, Nissan Headquarters (18 Stations)}

Nissan has completed 18 solar-assisted charging stations at its Franklin headquarters.

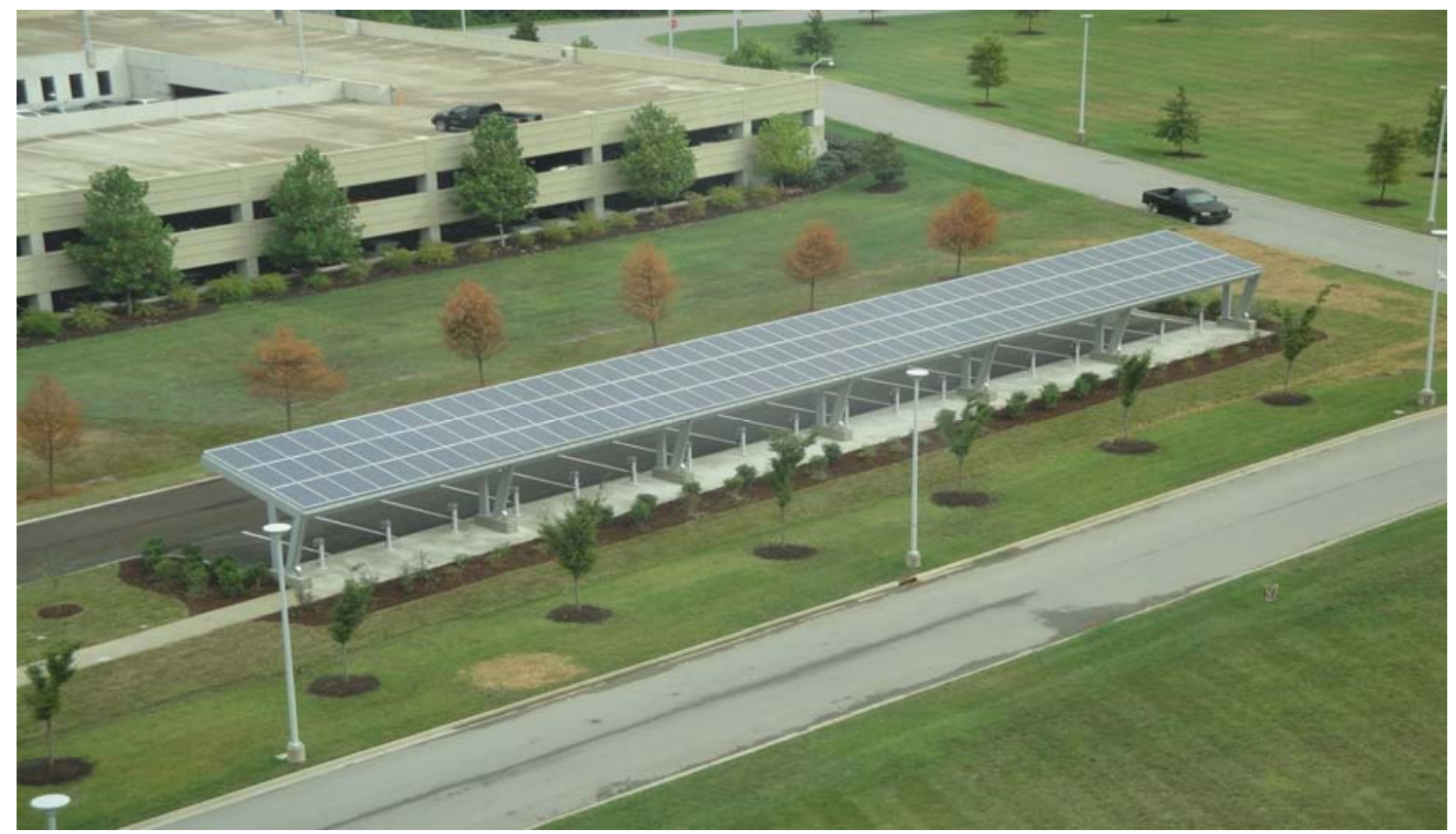

Franklin, Nissan Headquarters Solar Canopy

Solar: The $38 \mathrm{~kW}$ Nissan solar canopy covering $18 \mathrm{EV}$ charging spaces is designed with Sharp NU-U235F1 modules rated at $235 \mathrm{~W}$ each. The modules are composed of mono-crystalline silicon solar cells, with a module efficiency of $14.4 \%$. The solar canopy measures approximately 175 by 17 feet in plan and is tilted 10 degrees toward the south. The structure is a moment-resisting frame constructed of rectangular hollow structural sections with four single main columns. The PV array is mounted on top of the steel with a Florian PV racking system that provides a weather-tight roof structure. The solar PV modules are electrically connected in series strings of nine modules each to provide DC voltage to a Xantrex GT30 DC to AC inverter. Sixteen such series strings are connected in parallel at two Solar BOS circuit combiners to form a bi-polar system, one negative combiner and one positive combiner.

Battery: The Nissan solar-assisted EV charging station is equipped with a single lithium ion battery out of a LEAF automobile. The battery storage component is a 90 $\mathrm{kW}$ lithium ion battery designed with a control system to shave electrical demand during peak charging periods. The use of LEAF lithium batteries for energy storage will provide a second-life use for the electric vehicle batteries. Most used batteries will have a $60-70 \%$ life remaining. The battery is rated at $24 \mathrm{kWh}$ and is stored in a conditioned electrical equipment room. The battery is charged by a special battery charger designed by Nissan, Schneider Electric, and Bonitron.

The battery is discharged to the utility grid utilizing a Xantrex GT 100 DC to AC inverter. This inverter is capable of discharging energy stored in the battery bank to the power grid to help offset load surges from EV charging. The discharge profile can be 
customized to maximize battery life, shave peak demands, and discharge at predefined outputs and to maximize energy to the grid.

EVSEs: Nissan has 18 EVSEs that are manufactured by AeroVironment, Inc. (AV) at their headquarters building. The AV EVSEs have internet connectivity and can be configured to use Wi-Fi, hardwire Ethernet, or CDMA (a cell phone protocol).

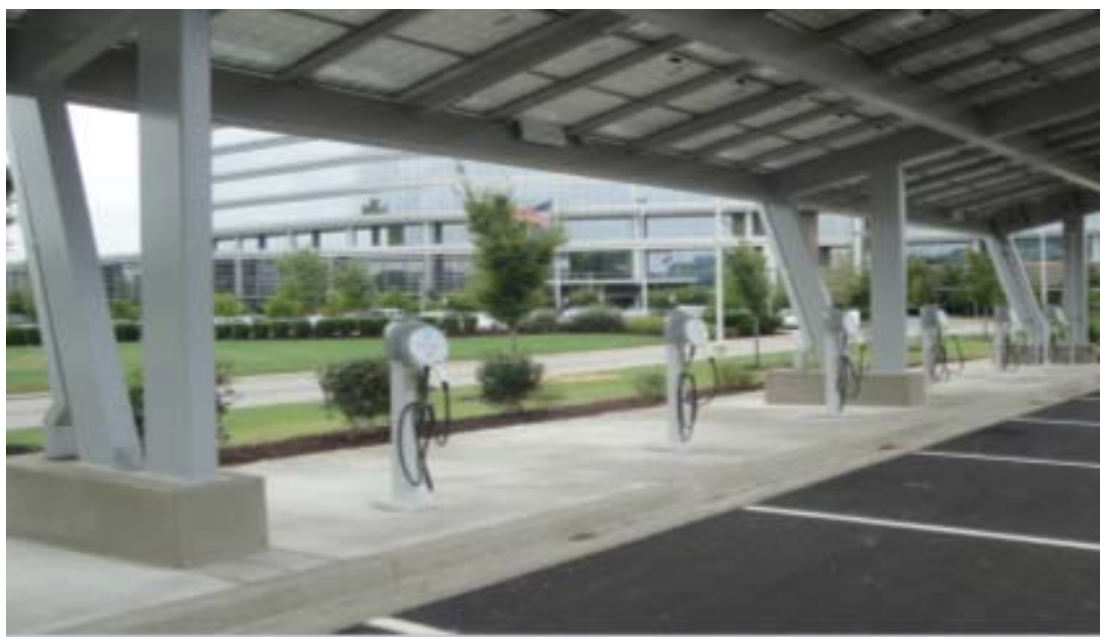

Franklin, Nissan Headquarters EVSEs

Data and Communications: TBD

A comparison of the components installed at ORNL, EPRI, and Nissan is shown below.

\begin{tabular}{|c|c|c|c|c|c|c|c|}
\hline \multicolumn{8}{|c|}{ EV Sites Component Comparison } \\
\hline \multirow[b]{2}{*}{ Sites } & \multicolumn{2}{|c|}{ EVSE } & \multicolumn{2}{|c|}{ Solar } & \multicolumn{3}{|c|}{ Battery } \\
\hline & Stations & Model & $\begin{array}{c}\text { Total } \\
\text { kW }\end{array}$ & Module & Type & $\begin{array}{c}\text { Capacity } \\
\text { kWh }\end{array}$ & Controller \\
\hline ORNL & 25 & Blink & 47 & Sharp & $\begin{array}{l}\text { C\&D } \\
\text { Technology }\end{array}$ & 84 & $\begin{array}{l}\text { SMA AG Snny Island } 5048 \\
\text { charger/inverter }\end{array}$ \\
\hline EPRI & 6 & Clipper Creek & 12 & $\begin{array}{l}\text { REC } \\
\text { Solar }\end{array}$ & GS Yuasa & 10 & Silent Power charger/inverter \\
\hline $\begin{array}{l}\text { Nissan } \\
\text { Smyrna }\end{array}$ & 10 & Blink & 19 & Sharp & $\begin{array}{l}\text { LEAF } \\
\text { lithium-ion }\end{array}$ & 24 & $\begin{array}{l}\text { Nissan/Schneider } \\
\text { Electric/Bomitron charger \& } \\
\text { Xantrex inverter }\end{array}$ \\
\hline $\begin{array}{l}\text { Nissan } \\
\text { Franklin }\end{array}$ & 17 & AeorVironment & 38 & Sharp & $\begin{array}{l}\text { LEAF } \\
\text { lithium-ion }\end{array}$ & 24 & $\begin{array}{l}\text { Nissan/Schneider } \\
\text { Electric/Bomitron charger \& } \\
\text { Xantrex inverter }\end{array}$ \\
\hline $\begin{array}{l}\text { Nissan } \\
\text { Battery } \\
\text { Plant }\end{array}$ & 3 & Blink & 6.5 & Sharp & $\begin{array}{l}\text { LEAF } \\
\text { lithium-ion }\end{array}$ & 24 & $\begin{array}{l}\text { Nissan/Schneider } \\
\text { Electric/Bomitron charger \& } \\
\text { Xantrex inverter }\end{array}$ \\
\hline
\end{tabular}




\section{F. Knoxville (10 Stations)}

ORNL is completing the procurement process to place a contract to install 10 solarassisted charging spaces in Knoxville. There will be four spaces at the Market Street Parking Garage and six spaces at the Coliseum Parking Garage. The assets will be transferred to the City at the end of the research project currently planned for September 30, 2012.

Solar: Design-build contract being bid at this time.

Battery: Design-build contract being bid at this time.

EVSEs: Design-build contract being bid at this time.

Data and Communications: TBD

\section{G. UTK (12 Stations)}

The construction package includes 12 charging stations on the UTK campus: six spaces at the Agriculture Campus and six at the Music Building Staff Parking Lot. An agreement between ORNL and UTK has been drafted. Assets will be transferred to UTK at the end of the project.

Solar: Design-build contract being bid at this time.

Battery: Design-build contract being bid at this time.

EVSEs: Design-build contract being bid at this time.

Data and Communications: TBD

\section{H. Nashville, Metro (Eight Stations)}

ORNL will install eight solar-assisted charging spaces at LP Field in Nashville. These spaces are also included in the previously mentioned construction package for Knoxville and UTK. An agreement between ORNL and the Nashville Metropolitan Government is being resolved. These stations will be turned over the Nashville Metropolitan Government at the end of the project.

Solar: Design-build contract being bid at this time.

Battery: Design-build contract being bid at this time.

EVSEs: Design-build contract being bid at this time.

Data and Communications: TBD 


\section{Nashville, State (Four Stations)}

Four solar-assisted charging stations are planned for State of Tennessee property at the Bicentennial Mall. These charging stations are also included in the previously mentioned bid package and similar concerns are being addressed.

Solar: Design-build contract being bid at this time.

Battery: Design-build contract being bid at this time.

EVSEs: Design-build contract being bid at this time.

Data and Communications: TBD

\section{J. Nashville, Vanderbilt (10 Stations)}

TVA and EPRI are collaborating on the installation of 10 solar-assisted charging stations on the Vanderbilt campus. These stations will be located in a parking area near Broadway Avenue. The site host agreement has been negotiated. Design and construction will be started in the near future.

Solar: To be determined during design process.

Battery: To be determined during design process.

EVSEs: To be determined during design process.

Data and Communications: TBD

\section{K. Chattanooga (10 Stations)}

TVA and EPRI are managing the installation of 10 solar-assisted charging stations in Chattanooga. Six of the spaces will be located in a site near the downtown area. Negotiation with the site host at this location is in progress. Four spaces, which are currently under construction, will be located at the TVA Advanced Vehicle Test Facility on the North side of the city.

Solar: To be determined during design process.

Battery: To be determined during design process.

EVSEs: To be determined during design process.

Data and Communications: TBD 


\section{Memphis (10 Stations)}

The TVA/ERPI partners are also managing the installation of 10 solar-assisted charging stations in Memphis. The site will be located at Shelby Farms Park near the main park office building. The site host agreement has been negotiated, and design and construction will commence in the near future.

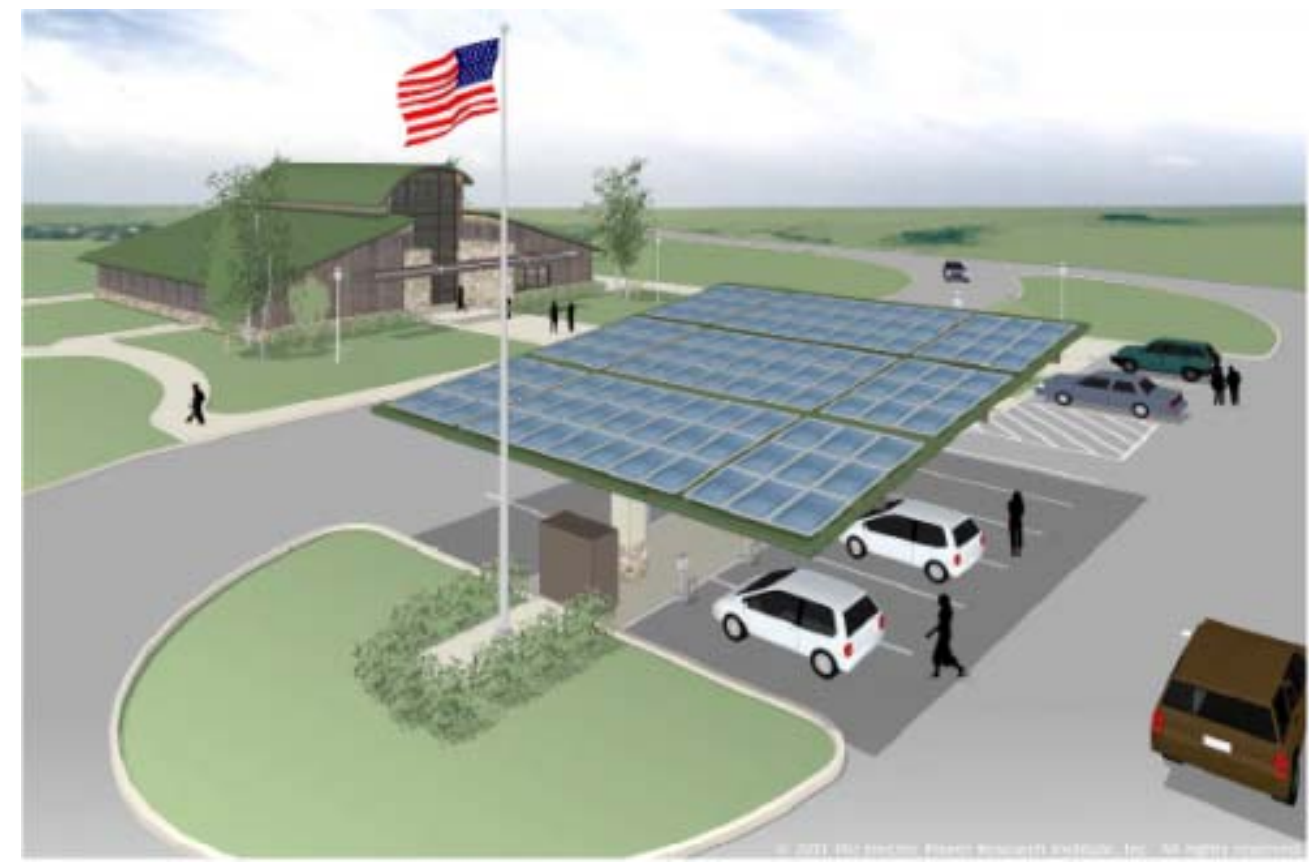

Draft Shelby Farms Site Artist's Concept

Solar: To be determined during design process.

Battery: To be determined during design process.

EVSEs: To be determined during design process.

Data and Communications: TBD

IV. Data Received from INL: INL is responsible for collecting, reducing, analyzing, and reporting data for the EV Project on a quarterly basis. Since the database contains information that could be considered personal (e.g., consumption by a particular vehicle), the raw data is protected and available only through INL in a reduced form. The INL report for the period July through August 2011 is included as Appendix A of this report. The report shows that during the period there were 278 charging events among the first 16 ORNL EVSEs put in service, consuming 2.31 MWh AC. While vehicles were connected to EVSEs $10 \%$ of the time, they were actively charging only $3 \%$ of the time. The demand will increase significantly over the next few reporting periods as more LEAFs are received by ORNL staff. 


\section{Lessons Learned - Technical Details}

1. Coordinate with utility providers early to determine optimum locations of the stations for access to power and the arrangement of meters.

2. Coordinate with information technology (IT) departments early to help avoid delays during startup due to internet connection, IT security plans, and development of equipment communication pathways.

3. Determine space availability for structure support systems early, especially within existing parking lots, to avoid affecting parking space availability.

4. Address drainage details during station design. Downspouts added at the end of the project tend to interfere with other components.

5. Plan for appropriate ground cover for ground areas shaded by the solar panels.

6. Develop a numbering system for the EVSEs to identify them for trouble shooting.

7. Coordinate with local parking enforcement officials to manage illegal parking in the EV spaces.

8. Coordinate with building and zoning officials early in the process to streamline approval and permitting of design, construction, and inspection.

9. Ensure that site access requirements and staging areas for construction are fully delineated and understood.

\section{Summary}

The solar-assisted EV charging station project has made great strides in fiscal year 2011. A total of 58 solar-assisted EV parking spaces have been commissioned in East and Middle Tennessee, and progress on installing the remaining 67 spaces is well underway. The contract for the 34 stations planned for Knoxville, UTK, and Nashville should be underway in October with completion scheduled for the end of March 2012; the remaining three Nissan stations are under construction and scheduled to be complete in November; and the EPRI/TVA stations for Chattanooga, Vanderbilt, and Memphis are underway and should be complete by the end of March 2012.

As additional Nissan LEAFs are being delivered, usage of the charging stations has increased substantially. The project is on course to complete all 125 solar-assisted EV charging stations in time to collect meaningful data by the end of government fiscal year 2012. Lessons learned from the sites completed thus far are being incorporated and are proving to be invaluable in completion of the remaining sites.

\section{Appendix A - INL EV Project Electric Vehicle Charging Infrastructure Summary Report (see next page)}




\section{EV Project Electric Vehicle Charging Infrastructure Summary Report}

Region: Oak Ridge National Laboratory

Report period: July 2011 through August 2011

Number of EV Project vehicles in region: 0

\section{Charging Unit Usage}

Residential Nonresidentia Level 2

Number of charging units ${ }^{1}$ Level 2

Level 2

Available

Number of charging events ${ }^{2}$

0

$0 \quad 16$

16

$0 \quad 278$

Electricity consumed (AC MWh)

0

Percent of time with a vehicle connected to charging unit

0.00

0.00

2.31

$0 \%$

$10 \%$

$0 \%$

$3 \%$

Charging Unit Utilization

\section{Number of Charge Events}

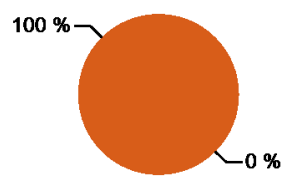
Residential Level 2
Private Nonresidential Level 2
Publicly Available Level 2

\section{Electricity Consumed}

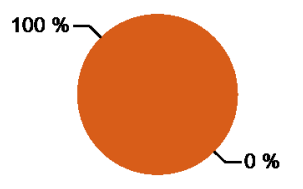

Residential Level 2

Private Nonresidential Level 2

Publicly Available Level 2

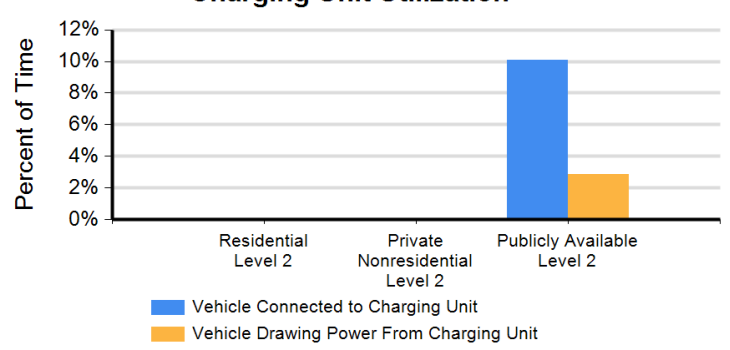

Charging Availability: Range of Percent of Charging Units with a Vehicle Connected versus Time of Day ${ }^{3}$
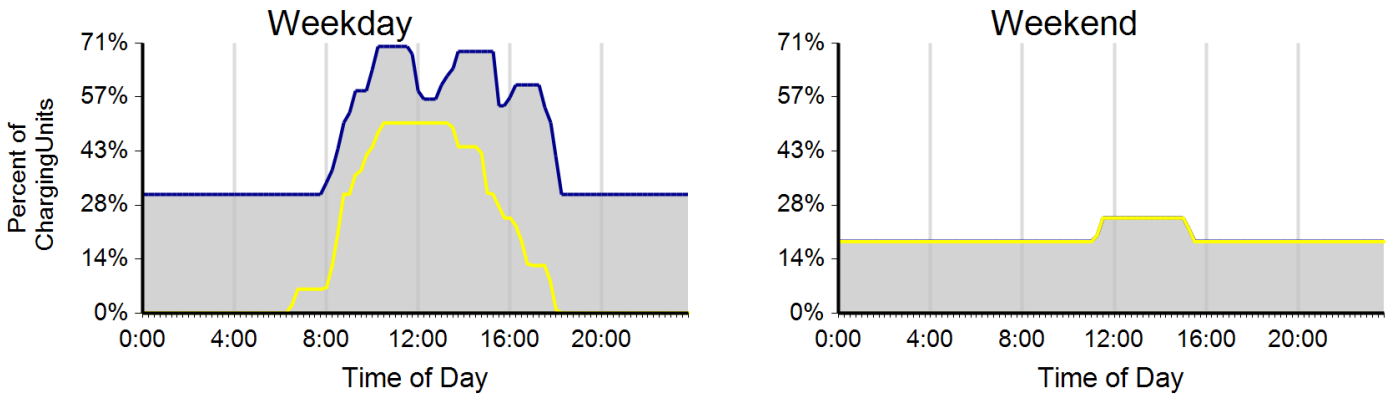

Max percentage of charging units connected across all days Min percentage of charging units connected across all days Percentage of charging units connected on single calendar day with peak electricity demand

Charging Demand: Range of Aggregate Electricity Demand versus Time of Day ${ }^{4}$
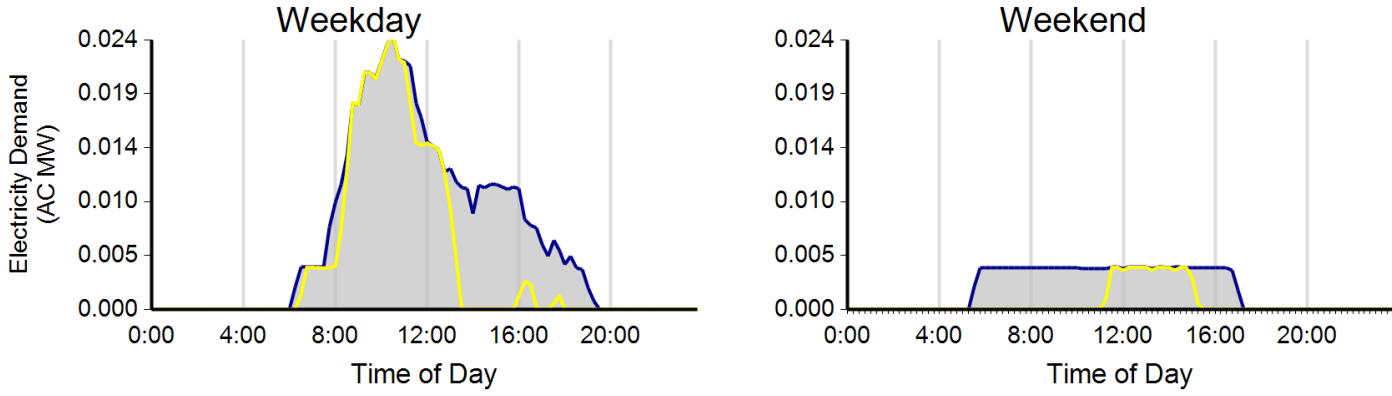

Max electricity demand across all days

Min electricity demand across all days

Electricity demand on single calendar day with highest peak

${ }^{1}$ Includes all charging units that were in use by the end of the reporting period

${ }^{2} \mathrm{~A}$ charging event is defined as the period when a vehicle is connected to a charging unit, during which period some power is transferred

${ }^{3}$ Considers the connection status of all charging units every minute

${ }^{4}$ Based on 15 minute rolling average power output from all charging units 


\section{Appendix B - EPRI Knoxville Charging Data}

\begin{tabular}{|c|c|c|}
\hline $100 \mathrm{CS}-1$ & 54 Vehicle Detection Total Count & \\
\hline $100 \mathrm{CS}-1$ & 54 Vehicle Detection Total Time & sec \\
\hline $100 \mathrm{CS}-1$ & 54 Vehicle Detection Status & \\
\hline $100 \mathrm{CS}-2$ & 55 Vehicle Detection Total Count & \\
\hline $100 \mathrm{CS}-2$ & 55 Vehicle Detection Total Time & sec \\
\hline $100 \mathrm{CS}-2$ & 55 Vehicle Detection Status & \\
\hline $100 \mathrm{CS}-3$ & 56 Vehicle Detection Total Count & \\
\hline $100 \mathrm{CS}-3$ & 56 Vehicle Detection Total Time & sec \\
\hline $100 \mathrm{CS}-3$ & 56 Vehicle Detection Status & \\
\hline $100 \mathrm{CS}-4$ & 57 Vehicle Detection Total Count & \\
\hline $100 \mathrm{CS}-4$ & 57 Vehicle Detection Total Time & sec \\
\hline $100 \mathrm{CS}-4$ & 57 Vehicle Detection Status & \\
\hline $100 \mathrm{CS}-5$ & 58 Vehicle Detection Total Count & \\
\hline $100 \mathrm{CS}-5$ & 58 Vehicle Detection Total Time & sec \\
\hline $100 \mathrm{CS}-5$ & 58 Vehicle Detection Status & \\
\hline $100 \mathrm{CS}-6$ & 59 Vehicle Detection Total Count & \\
\hline $100 \mathrm{CS}-6$ & 59 Vehicle Detection Total Time & sec \\
\hline $100 \mathrm{CS}-6$ & 59 Vehicle Detection Status & \\
\hline 101PV & 52 IrradiancePOA & $\mathrm{W} / \mathrm{m}^{\wedge} 2$ \\
\hline 101PV & 52 IrradiancePOA Avg & $\mathrm{W} / \mathrm{m}^{\wedge} 2$ \\
\hline $101 P V$ & 52 IrradiancePOA Min & $\mathrm{W} / \mathrm{m}^{\wedge} 2$ \\
\hline 101PV & 52 IrradiancePOA Max & $\mathrm{W} / \mathrm{m}^{\wedge} 2$ \\
\hline 101PV & 52 ModuleTemp & ${ }^{\circ} \mathrm{F}$ \\
\hline $101 P V$ & 52 ModuleTemp Avg & ${ }^{\circ} \mathrm{F}$ \\
\hline $101 P V$ & 52 ModuleTemp Max & ${ }^{\circ} \mathrm{F}$ \\
\hline $101 \mathrm{PV}$ & 52 ModuleTemp Min & ${ }^{\circ} \mathrm{F}$ \\
\hline 123 Battery & 53 Current $A$ & A \\
\hline 123Battery & 53 CurrentB & A \\
\hline 123 Battery & 53 PowerTotal & W \\
\hline 123Battery & 53 ReacPowerTotal & VAR \\
\hline 123Battery & 53 EnergyTotalReceived (Positive) & kWh \\
\hline 123 Battery & 53 EnergyTotalDelivered (Negative) & $\mathrm{kWh}$ \\
\hline 123 Battery & 53 EnergyTotalNet & kWh \\
\hline 123Battery & 53ReacEnergyTotalPositive & kVARh \\
\hline 123 Battery & 53 ReacEnergyTotalNegative & kVARh \\
\hline 123Battery & 53 ReacEnergyTotalNet & kVARh \\
\hline 124PV & 52 CurrentA & $A$ \\
\hline $124 \mathrm{PV}$ & 52 CurrentB & A \\
\hline 124PV & 52 PowerTotal & W \\
\hline 124PV & 52 ReacPowerTotal & VAR \\
\hline $124 \mathrm{PV}$ & 52 EnergyTotalReceived (Positive) & kWh \\
\hline $124 \mathrm{PV}$ & 52 EnergyTotalDelivered (Negative) & kWh \\
\hline $124 \mathrm{PV}$ & 52 EnergyTotalNet & kWh \\
\hline 124PV & 52 ReacEnergyTotalPositive & kVARh \\
\hline $124 \mathrm{PV}$ & 52 ReacEnergyTotalNegative & kVARh \\
\hline $124 \mathrm{PV}$ & 52 ReacEnergyTotalNet & kVARh \\
\hline 126 Main & 51 VoltageAN & V \\
\hline 126 Main & 51 VoltageBN & V \\
\hline 126 Main & 51 Voltage $A B$ & $\mathrm{~V}$ \\
\hline 126 Main & 51 CurrentA & A \\
\hline 126 Main & 51 CurrentB & A \\
\hline 126 Main & 51 PowerTotal & W \\
\hline 126 Main & 51 ReacPowerTotal & VAR \\
\hline 126 Main & 51 Frequency & $\mathrm{Hz}$ \\
\hline 126 Main & 51 EnergyTotalReceived (Positive) & kWh \\
\hline 126 Main & 51 EnergyTotalDelivered (Negative) & kWh \\
\hline 126 Main & 51EnergyTotalNet & kWh \\
\hline 126 Main & 51ReacEnergyTotalPositive & kVARh \\
\hline 126 Main & 51 ReacEnergyTotalNegative & kVARh \\
\hline 126 Main & 51 ReacEnergyTotalNet & kVARh \\
\hline
\end{tabular}




\begin{tabular}{|c|c|c|}
\hline $130 \mathrm{CS}-1$ & 54 EnergyTotalReceived (Positive) & Wh \\
\hline $130 \mathrm{CS}-1$ & 54PowerTotal & W \\
\hline $131 \mathrm{CS}-2$ & 55 EnergyTotalReceived (Positive) & Wh \\
\hline $131 \mathrm{CS}-2$ & 55 PowerTotal & W \\
\hline $132 \mathrm{CS}-3$ & 56 EnergyTotalReceived (Positive) & Wh \\
\hline $132 \mathrm{CS}-3$ & 56 PowerTotal & W \\
\hline $133 \mathrm{CS}-4$ & 57 EnergyTotalReceived (Positive) & Wh \\
\hline $133 \mathrm{CS}-4$ & 57 PowerTotal & W \\
\hline $134 \mathrm{CS}-5$ & 58 EnergyTotalReceived (Positive) & Wh \\
\hline $134 \mathrm{CS}-5$ & 58 PowerTotal & W \\
\hline $135 \mathrm{CS}-6$ & 59 EnergyTotalReceived (Positive) & Wh \\
\hline $135 \mathrm{CS}-6$ & 59 PowerTotal & W \\
\hline
\end{tabular}

